migration, which will be resisted as states reach their absorptive capacity. Closed borders could aggravate the desperation and lead, as in the past, to the development of bizarre ideologies and aggressive tendencies. There will be no possibility of quarantine.

VII.

In some eschatologies, debate rages over whether there will be a need for law of any sort after the arrival of the Messiah. The international political system is at the threshold of a time of hope. The ending of the Cold War is a major achievement, but we are not about to enter the millennium. "This annus," as Auden said, "is not mirabilis." The need for international law after the Cold War will be more urgent than it was during the conflict. In many ways, what is expected of international law will be greater.

In a period of rapid change, no system of law can content itself with a pious, mechanical replication of the past, for the future may be quite different from the past. Replication may then be a formula, not for reachieving what was gained in the past, but for disaster. The challenge to international lawyers and scholars must be to clarify continuously the common interests of this ever-changing community, drawing on historic policies but bearing in mind that the constitutive and institutional arrangements that were devised to achieve them may no longer be pertinent or effective.

W. MichaEl REISMAN

\title{
SOVEREIGNTY AND HUMAN RIGHTS IN CONTEMPORARY INTERNATIONAL LAW
}

anachronism . . . 1: an error in chronology; esp: a chronological misplacing of persons, events, objects or customs in regard to each other . . 2: a person or a thing that is chronologically out of place; esp: one that belongs to a former age and is incongruous if found in the present....

Webster's Third International Dictionary

I.

Since Aristotle, the term "sovereignty" has had a long and varied history during which it has been given different meanings, hues and tones, depending on the context and the objectives of those using the word. ${ }^{1}$ Bodin and Hobbes shaped the term to serve their perception of an urgent need for internal order. Their conception influenced several centuries of international politics and law ${ }^{2}$ and also became a convenient supplementary secular

\footnotetext{
'See [Installment] 10 Encyclopedia of Public International Law 397, 399 (R. Bernhardt ed. 1989) (discussion of historical evolution of term "sovereignty" from Aristotle to present).

${ }^{2}$ Id. at 401-02.
} 
slogan for the various absolute monarchies of the time. Sovereignty often came to be an attribute of a powerful individual, whose legitimacy over territory (which was often described as his domain and even identified with him) rested on a purportedly direct or delegated divine or historic authority but certainly not, Hobbes's covenant of the multitude ${ }^{3}$ notwithstanding, on the consent of the people.

The public law of Europe, the system of international law established by the assorted monarchs of the continent to serve their common purposes, reflected and reinforced this conception by insulating from legal scrutiny and competence a broad category of events that were later enshrined as "matters solely within the domestic jurisdiction." "If another political power entered the territory of the sovereign (whatever the reason) without his permission, his sovereignty was violated. In such matters, the sovereign's will was the only one that was legally relevant.

With the words "We the People," 5 the American Revolution inaugurated the concept of the popular will as the theoretical and operational source of political authority. On its heels, the French Revolution and the advent of subsequent democratic governments confirmed the concept. Political legitimacy henceforth was to derive from popular support; governmental authority was based on the consent of the people in the territory in which a government purported to exercise power. At first only for those states in the vanguard of modern politics, later for more and more states, the sovereignty of the sovereign became the sovereignty of the people: popular sovereignty.

It took the formal international legal system time to register these profound changes. Another century beset by imperialism, colonialism and fascism was to pass, but by the end of the Second World War, popular sovereignty was firmly rooted as one of the fundamental postulates of political legitimacy. Article 1 of the UN Charter established as one of the purposes of the United Nations, to develop friendly relations between states, not on any terms, but "based on respect for the principles of equal rights and self-determination of peoples."

Any lingering doubt that use of the term "self-determination" might have amounted to a mechanical, or at best a deferential, carry-over from Wilsonian diplomacy, and not a radical decision that henceforth the internal authority of governments would be appraised internationally, was dispelled three years later. In the Universal Declaration of Human Rights, a document then describing itself as "a common standard of achievement" but now accepted as declaratory of customary international law, Article 21(3) provided that "[t]he will of the people shall be the basis of the authority of government; this will shall be expressed in periodic and genuine elections which shall be

\footnotetext{
3 T. Hobbes, Leviathan (M. Oakeshott ed. 1946).

4 Under Article 15(8) of the Covenant of the League of Nations, if the Council found a dispute between any two parties "to arise out of a matter which by international law is solely within the domestic jurisdiction of that party," the Council would refrain from making any recommendation as to its settlement. See LEAGUE of Nations Covenant Art. 15, para. 8, it pront'd in 13 AJIL 128, 134 (Supp. 1919).

U.S. CONST., Preamble.
} 
by universal and equal suffrage and shall be held by secret vote or by equivalent free voting procedures." 6 Of course, there had been regional pacts based upon similar notions, ${ }^{7}$ much as there had been holy alliances based on their antithesis. The significance of this statement in the Universal Declaration was that it was now expressed in a fundamental international constitutive legal document. In international law, the sovereign had finally been dethroned.

Unlike certain other grand statements of international law, the concept of popular sovereignty was not to remain mere pious aspiration. The international lawmaking system proceeded to prescribe criteria for appraising the conformity of internal governance with international standards of democracy. ${ }^{8}$ Thanks to a happy historical conjunction, modern communications technology has made it possible to verify that conformity rapidly and economically and to broadcast it widely. International and regional organizational monitors now use the new technology in critical national elections so as to ensure that they are free and fair. ${ }^{9}$ The results of such elections serve as evidence of popular sovereignty and become the basis for international en-

\footnotetext{
${ }^{6}$ Universal Declaration of Human Rights, GA Res. 217A (III), UN Doc. A/810, at 71 (1948).

${ }^{7}$ See, e.g., Central American Treaty of Peace (Treaty of Washington), Additional Convention to the General Treaty, Art. I, 2 Foreign RELATIONS OF THE UNITEd STATES 1907, at 696, 696, reprinted in 2 AJIL 229, 229-30 (Supp. 1908):
}

The Governments of the High Contracting Parties shall not recognize any other Government which may come into power in any of the five Republics as a consequence of a coutp d'etat, or of a revolution against the recognized Government, so long as the freely elected representatives of the people thereof have not constitutionally reorganized the country.

${ }^{8}$ See, for example, United Nations Declaration on the Elimination of All Forms of Racial Discrimination, GA Res. 1904 (XVIII) (Nov. 20, 1963); International Convention on the Elimination of All Forms of Racial Discrimination, opened for signalure Mar. 7, 1966, 660 UNTS 195; International Convention on the Suppression and Punishment of the Crime of Apartheid, GA Res. 3068 (XXVIII) (Nov. 30, 1973); Convention against Discrimination in Education, Dec. 14, 1960, 429 UNTS 32; Convention concerning Equal Remuneration for Men and Women Workers for Work of Equal Value, June 29, 1951, 165 UNTS 303; Convention on the Elimination of All Forms of Discrimination against Women, GA Res. 34/180 (Dec. 18, 1979); Declaration on the Elimination of All Forms of Intolerance and of Discrimination Based on Religion or Belief, GA Res. 36/55 (Nov. 25, 1981); Convention concerning Forced or Compulsory Labour, June 28, 1930, 39 UNTS 55; Declaration on the Protection of All Persons from Being Subjected to Torture and Other Cruel, Inhuman or Degrading Treatment or Punishment, GA Res. 3452 (XXX) (Dec. 9, 1975); Convention against Torture and Other Cruel, Inhuman or Degrading Treatment or Punishment, GA Res. 39/46 (Dec. 10, 1984); Code of Conduct for Law Enforcement Officials, GA Res. 34/169 (Dec. 17, 1979); and Declaration of Basic Principles of Justice for Victims of Crime and Abuse of Power, GA Res. 40/34 (Nov. 29, 1985); as well as the numerous conventions on social welfare, marriage and the family and cultural rights. See also Resolutions Adopted by the General Assembly During its 20th Session, 20 UN GAOR Supp. (No. 14) at 53-65, UN Doc. A/6014 (1965) (series of resolutions adopted on non-selfgoverning territories).

${ }^{9}$ For example, in the recently concluded Namibia elections, the ballot counting and tabulation were overseen by 1,700 electoral supervisors, part of a United Nations Transition Assistance Group (UNTAG). See UN CHRON., March 1990, at 42. Similarly, a UN observation mission for the verification of elections in Nicaragua (ONUVEN) was set up there in December 1989 to observe and monitor the 1990 elections. Id. at 64 . 
dorsement of the elected government. ${ }^{10}$ In functional terms, this process constitutes a new type of inclusive international recognition. Decisions to withhold recognition where the will of the people has been demonstrably ignored or suppressed have increasingly led to the next stage, the institution of international programs designed to permit or facilitate the realization of the popular will. ${ }^{11}$

II.

Although the venerable term "sovereignty" continues to be used in international legal practice, its referent in modern international law is quite different. International law still protects sovereignty, but-not surprisinglyit is the people's sovereignty rather than the sovereign's sovereignty. Under the old concept, even scrutiny of international human rights without the permission of the sovereign could arguably constitute a violation of sovereignty by its "invasion" of the sovereign's domaine réservé. The United Nations Charter replicates the "domestic jurisdiction-international concern" dichotomy, but no serious scholar still supports the contention that internal human rights are "essentially within the domestic jurisdiction of any state" and hence insulated from international law.

This contemporary change in content of the term "sovereignty" also changes the cast of characters who can violate that sovereignty. Of course,

10 After the November 1989 elections in Namibia, the UN Security Council congratulated the people of Namibia and affirmed the election results; the Special Committee on Decolonization declared on December 4 that the Namibian elections had been held "in conformity with established UN standards of decolonization"; and Special Representative Ahtisaari declared that the electoral process had "at each stage been free and fair." See id. at 41-43.

11 After Rhodesia's unilateral declaration of independence in 1965, the international community overwhelmingly denounced the action and refused to recognize Rhodesia as one independent state. See generally The Situation in Southern Rhodesia: Resolutions Adopted by the General Aswmbly and the Security Council of the United Nations, reprinted in 60 AJIL 921 (1966). For commentary, see McDougal \& Reisman, Rhodesia and the United Nations: The Lawfulness of Interuntoral Conctm, 62 AJIL I (1968).

With respect to Namibia, the United Nations consistently refused to recognize South Africa's occupation of Namibia. See, e.g., Marín-Bosch, How Nations Vote in the General Assembly of the Umted Nations, 41 INT'L ORG. 705, 705-06 (1987) (pointing out that Namibia was the subject of more resolutions than all other past decolonization issues combined). Indeed, by Resolution 2145 (XXI) of October 27, 1966, the General Assembly placed Namibia under the direct responsibility of the United Nations so as to enable Namibians to exercise their right of self-determination. It also established the UN Council for Namibia (by Resolution 2248 (S-V) of May 19, 1967) with the objective, inter alia, of obtaining the withdrawal of South Africa from Numibia. $S^{\prime} t^{\prime}$ Report of the United Nations Council for Namibia, 39 UN GAOR Supp. (No. 24) at 1. UN Doc. A/39/24 (1984). Other international programs eventually led to the independence of Namibia on March 21, 1990.

The South African situation has also gained the attention of the international community in the past few' decades. See, e.g., the Policies of Apartheid of the Government of the Republic of South Africa, GA Res. 3151 (XXVIII), 28 UN GAOR Supp. (No. 30) at 33, UN Doc. A/9030 (1973); GA Res. 39/72, 39 UN GAOR Supp. (No. 51) at 40, UN Doc. A/39/51 (1985); International Convention on the Suppression and Punishment of the Crime of Apartheid, GA Res. 3068 (XXVIII), 28 UN GAOR Supp. (No. 30), supra, at 75. Talks are currently under way to work out a form of representative government for a future South Africa. See Waldmeir, $A N C$ Mrey End Armed Struggle, Fin. Times (London), May 5, 1990, at 1, col. 7. 
popular sovereignty is violated when an outside force invades and imposes its will on the people. One thinks of the invasion of Afghanistan in 1979 or of Kuwait in $1990 .{ }^{12}$ But what happens to sovereignty, in its modern sense, when it is not an outsider but some home-grown specialist in violence who seizes and purports to wield the authority of the government against the wishes of the people, by naked power, by putsch or by coup, by the usurpation of an election or by those systematic corruptions of the electoral process in which almost 100 percent of the electorate purportedly votes for the incumbent's list (often the only choice)? Is such a seizer of power entitled to invoke the international legal term "national sovereignty" to establish or reinforce his own position in international politics?

Under the old international law, the internal usurper was so entitled, for the standard was de facto control: the only test was the effective power of the claimant. In the Tinoco case, ${ }^{13}$ Costa Rica sought to defend itself by claiming a violation of its popular sovereignty. Tinoco, the erstwhile Minister of War, had seized power in violation of the Constitution. Therefore, the subsequent restorationist Costa Rican Government contended, his actions could not be deemed to have bound Costa Rica. But Chief Justice Taft decided that by virtue of his effective control, Tinoco had represented the legitimate government as long as he enjoyed that control.

The Tinoco decision was consistent with the law of its time. Were it applied strictly now, it would be anachronistic, for it stands in stark contradiction to the new constitutive, human rights-based conception of popular sovereignty. To be sure, there were policy reasons for Tinoco, which may still have some cogency, but the important point is that there was then no countervailing constitutive policy of international human rights and its conception of popular sovereignty.

Caudillos and their like appear to be susceptible to a megalomania that identifies their corporeal selves with the symbols of the nation and the state. They invoke a "'sovereignty' so grandiose and capricious . . . it might be supposed to be a deliberate caricature, save for the intensity of the sentiments that are mobilized around the symbol itself." "Happily, the international legal system in which declamations such as "l'état, c'est moi" were coherent has long since been consigned to history's scrap heap. In our era, such pronouncements become, at least for audiences at a safe remove, the stuff of refined comedy. They would be occasions for general hilarity, even in the countries where they are still staged, were it not for the endless misery that the dictators who grant themselves sovereignty always inflict upon the human beings trapped within the boundaries of the territory the dictators have confused with themselves.

\footnotetext{
${ }^{12}$ On the invasion of Afghanistan by the Soviet Union and the applicable norms of armed conflict, see generally Reisman \& Silk, Which Law Applies to the Afghan Conflict?, 82 AJIL 459 (1988).

13 Tinoco case (Great Brit. v. Costa Rica), 1 R. Int'l Arb. Awards 369 (1923), reprinted in 18 AJIL 147 (1924).

${ }^{14}$ McDougal, Lasswell \& Reisman, The World Constitutive Process of Authorilative Decision, in M. S. MCDOUgal \& W. M. REISMAN, INTERNATIONAL LAW EsSays 197 (1981).
} 
III.

In many countries, the internal political situation is murky and constitutional procedures for the orderly transfer of power are nonexistent or ineffective. In a flurry of coups and putsches, both outsiders and insiders may be unable to ascertain the popular will, especially if the disorder or tyranny has prevented it from being consulted or expressed. Even in the absence of elections-indeed, even when there are "supervised" elections-it is often clear that the vast majority of the people detest those who have assumed power and characterize themselves as the government. It is more difficult, however, to say who the people would wish in their stead. They may not know, which is one of the reasons that international legal supervision of elections is designed to include an adequate period for candidacies to be developed and to allow campaigning, so that voters can make the informed choice that is at the center of free and fair elections.

But in circumstances in which free elections are internationally supervised and the results are internationally endorsed as free and fair and the people's choice is clear, the world community does not need to speculate on what constitutes popular sovereignty in that country.

When those confirmed wishes are ignored by a local caudillo who either takes power himself or assigns it to a subordinate he controls, a jurist rooted in the late twentieth century can hardly say that an invasion by outside forces to remove the caudillo and install the elected government is a violation of national sovereignty. Cross-border military actions should certainly never be extolled, for they are necessarily brutal and destructive of life and property. They may well be unlawful for a variety of other reasons. But if they displace the usurper and emplace the people who were freely elected, they can be characterized, in this particular regard, as a violation of sovereignty only if one uses the term anachronistically to mean the violation of some mystical survival of a monarchical right that supposedly devolves jure gentium on whichever warlord seizes and holds the presidential palace or if the term is used in the jurisprudentially bizarre sense to mean that inanimate territory has political rights that preempt those of its inhabitants. ${ }^{15}$

This is not to say that every externally motivated action to remove an unpopular government is now permitted, or that officer corps that feel obsolescence hard upon them can claim a new raison d'être and start scouring the globe for opportunities for "democratizing" interventions. Authoritative conclusions about the lawfulness of the unilateral use of force, no less than about any other unilateral action, turn on many contextual factors: e.g., the contingencies allegedly justifying the unilateral use, the availability of feasible persuasive alternatives, the means of coercion selected, the level of coercion used (the classic test of necessity and proportionality), whether the ob-

\footnotetext{
${ }^{13}$ Sik Stone, Should Trees Have Standing?-Toward Legal Rights for Natural Objects, 45 S. CAL. L. REV. 450 (1972); Tribe, Ways Not to Think about Plastic Trees: New Foundations for Environmental Lai 83 YALE L.J. 1315 (1974). For a cogent critique on this point, cf. Schwartz, The Rights of Nather and the Death of God, PuB. INTEREsT, No. 97, 1989, at 3.
} 
jectives of the intervener include internationally illicit aims, the aggregate consequences of inaction, and the aggregate consequences of action. ${ }^{16}$ But it is to say that the suppression of popular sovereignty may be a justifying factor, not a justification per se but a conditio sine qua non. And it is to say that the word "sovereignty" can no longer be used to shield the actual suppression of popular sovereignty from external rebuke and remedy.

International law is still concerned with the protection of sovereignty, but, in its modern sense, the object of protection is not the power base of the tyrant who rules directly by naked power or through the apparatus of a totalitarian political order, but the continuing capacity of a population freely to express and effect choices about the identities and policies of its governors. In modern international law, the "unilateral declaration of independence" by the Smith Government in Rhodesia was not an exercise of national sovereignty but a violation of the sovereignty of the people of Zimbabwe. ${ }^{17}$ The Chinese Government's massacre in Tiananmen Square to maintain an oligarchy against the wishes of the people was a violation of Chinese sovereignty. The Ceausescu dictatorship was a violation of Romanian sovereignty. President Marcos violated Philippine sovereignty, General Noriega violated Panamanian sovereignty, and the Soviet blockade of Lithuania violated its sovereignty. Fidel Castro violates Cuban sovereignty by mock elections that insult the people whose fundamental human rights are being denied, no less than the intelligence of the rest of the human race. In each case, the violators often brazenly characterize the international community's condemnation as itself a violation of their sovereignty. Sadly, some organizations and some scholars, falling victim to anachronism, have given them comfort.

In modern international law, sovereignty can be violated as effectively and ruthlessly by an indigenous as by an outside force, in much the same way that the wealth and natural resources of a country can be spoliated as thoroughly and efficiently by a native as by a foreigner. ${ }^{18}$ Sovereignty can be liberated as much by an indigenous as by an outside force. As in the interpretation of any other event in terms of policy, context and consequence must be considered.

IV.

The international human rights program is more than a piecemeal addition to the traditional corpus of international law, more than another chapter sandwiched into traditional textbooks of international law. By shifting the fulcrum of the system from the protection of sovereigns to the protection of people, it works qualitative changes in virtually every component. Many of the old terms survive, but in using them in a modern context, one should bear in mind Holmes's lapidary dictum: "A word is not a crystal,

\footnotetext{
${ }^{16}$ See M. S. McDougal \& F. Feliciano, Law and Minimum World Public Order, ch. 3 (1961).

${ }^{17}$ See supra note 11.

${ }^{18}$ See Reisman, Harnessing International Law' to Restrain and Recapture Indigenous Spoliations, 83 AJIL 56 (1989).
} 
transparent and unchanged; it is the skin of a living thought and may vary greatly in color and content according to the circumstances and the time in which it is used." 19

When constitutive changes such as these are introduced into a legal system while many other struts of the system are left in place, appliers and interpreters of current cases cannot proceed in a piecemeal and mechanical fashion. Precisely because the human rights norms are constitutive, other norms must be reinterpreted in their light, lest anachronisms be produced. This process of "updating" or "contemporization" or actualisation, as French scholars call it, is not unknown to international law. In the South-West Africa opinion, ${ }^{20}$ the International Court indicated the absurdity of mechanically applying an old norm without reference to fundamental constitutive changes, and national courts have often expressed the need and authority to actualize. ${ }^{21}$ The same style of actualization is required with regard to the assessment of the lawfulness of human rights actions. When this is not done, legal arguments and judgments will be marked by anachronism.

In the debate over the U.S. action in Panama in the United Nations, the Nicaraguan Permanent Representative, whose Government had requested the meeting, opened it by proclaiming: "Once again an offence has been committed against our peoples. Once again an attempt is being made to make brute force appear to be law. Once again the principles which are the foundation of international relations have been violated." 22 The Permanent Representative proceeded to cite, chapter and verse, the United Nations Charter and the OAS Charter to establish "[ $t]$ his flagrant violation of Panama's sovereignty and territorial integrity." ${ }^{23}$ No reference whatsoever was made to Manuel Antonio Noriega's suppression of popular sovereignty, or to the fact that both the internationally supervised election before the military action and the opinion polls after it indicated overwhelming support for the change that was realized. ${ }^{24}$ These issues were swept away by indirection, when the Permanent Representative said that "no argument can possibly justify intervention against a sovereign state." 25

19 Towne v. Eisner, 245 U.S. 372, 376 (1918).

${ }^{20}$ South-West Africa-Voting Procedure, 1955 ICJ REP. 67, 77 (Advisory Opinion of Junt 7 ).

${ }^{2 K}$ M. S. MCDOUgal, H. LASSWell \& J. Miller, THE INTERPRetation of Agreements AND World PUBlic ORder, ch. 4 (1967).

12 UN Doc. S/PV.2899, at 3-5 (Dec. 20, 1989). I treat this statement as made in good faith. It is not inappropriate to note, however, that those who invoke this argument frequently reserve for their governments a right of intervention for various revolutionary purposes, e.g., wars of national liberation. See, in this regard, Reisman, Old Wine in New Bottles: The Reagan and

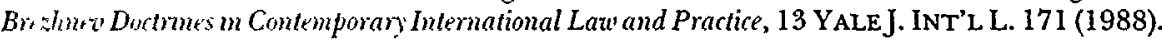

24 UN Doc. S/PV.2899, supra note 22, at 4.

2 One of the more ironic aspects of the Panama affair was that all indications before and after the U.S. invasion were that while the vast majority of the Panamanian people viewed it as a liberation, the other governments of the region voted in the OAS to condemn it as a violation of Panamanian sovereignty. According to most news reports, the U.S. military action in Panama was met with overwhelming approval by the Panamanian people. See, e.g., After Noriega, EconoMIST, Jan. 16, 1990, at 37.

${ }^{2 *}$ UN Doc. S/PV.2902, at 7 (Dec. 23, 1989). 
This is what Professor D'Amato, in his remarkable article, has called "the rhetoric of statism." 26 The anachronism here is effected by the selective use of the language of international law, carefully screening out everything that has been introduced by the human rights movement. It may be contrasted with the remark of Thomas Pickering, the United States Permanent Representative, that "the people, not governments, are sovereign." ${ }^{27}$ That formulation, in turn, oversimplifies the decision calculus now required, for, as expressed, it could make that single variable determinative of lawfulness in all future cases. But at least it expresses the critical new constitutive policy in international law, which is completely absent from the Nicaraguan formula.

Under the Nicaraguan version, sovereignty is not international protection of the will of the people, but international protection for a group that calls itself the government against the wishes of the people. There is no international test of the legitimacy of a self-proclaimed government. The only test is internal naked power. Under this version, Panama's sovereignty is violated by the removal of the usurper and the establishment of conditions for the assumption of power by the legitimate government. That is an anachronism.

Anachronism can only be avoided in legal decision by systematic actualization, which considers inherited norms in the context of changed constitutive normative systems and makes sensitive assessments of the relative weight each is to be given and the various intensities with which each is demanded.

V.

The consequences of these changes are far-reaching. Some are clearly beneficial to the new values of the international system. Some hold the potential for destabilizing the system. On the credit side, international human rights puts current and erstwhile tyrants on notice that monarchical and elitist conceptions of national sovereignty cannot be invoked to immunize them from the writ of international law. Some have already grasped the implications of this development. Haiti, in July 1990, asked the United Nations to provide three hundred civilian officials to supervise its upcoming elections and forty military officers to ensure that the local armed forces would be part of the solution rather than part of the problem. ${ }^{28}$ Haiti's provisional Foreign Minister, Kesler Clermont, said such a team would set "a powerful precedent" for UN monitoring of Third World elections "to certify their legitimacy." ${ }^{29}$ Three of the seven Third World members of the Security Council opposed the request. ${ }^{30}$ The princes may not like this, but for peoples languishing under despotism and dictatorship, the development promises, at least, the condemnation by international law of the violation of their sovereignty and the possibility, uncertain as it may be, of a remedy.

\footnotetext{
${ }^{26}$ D'Amato, The Invasion of Panama Was a Lawful Response to Tyranny, 84 AJIL 516, 518 (1990).

${ }^{27}$ UN Doc. S/PV.2902, supra note 25, at 8.

${ }^{28}$ Lewis, Haiti Wants U.N. to Monitor Vote, N.Y. Times, July 22, 1990, at 10, col. 6.

${ }^{29} \mathrm{Id}$. 
On the debit side, while the bite of human rights norms is extended, so, too, is systemic instability. In decentralized systems whose members themselves perforce make the decisions, the more the number of constitutive appraisal norms, the more the number of cross-border appraisals and the greater the possibility of cross-border meddling by various actors. The problem is contained, to an extent, when internationally supervised "free and fair" elections credibly and unequivocally indicate the wishes of a majority of the people. It is also contained when other nonelectoral indicators show the popular will, though without the clarity and freedom vouchsafed by secret ballot. When popular wishes are usurped violently, the confirmed expression of popular sovereignty tells everyone who the real usurper is and who should rightfully constitute the government, no matter how convincing the newspeak of the dictator's apparatus may be.

Unambiguous situations, however, may be exceptions. When the internationally supervised elections result in an absence of consensus on who should govern, or the integrity of the elections is doubtful, or there have been no elections, or a civil insurrection has left diverse groups vying for power, no one can be sure that the unilateral intervener from the outside is implementing popular wishes. To varying extents, the intervener will be shaping them. In some circumstances, the banner of popular sovereignty can become a fig leaf for its suppression by foreign intervention, especially when governments bent on intervention maintain stables of alternative local leaders who can be brought forward to authorize an invasion at the appropriate time. ${ }^{31}$ In practice, therefore, there may be a factual "gray" area between unequivocal expressions of popular will through internationally supervised, observed or validated elections, on the one hand, and the atrocities that warrant humanitarian intervention, on the other. Situations falling into the gray area will simply not lend themselves to unilateral action.

The most satisfactory solution to this problem is the creation of centralized institutions, equipped with decision-making authority and the capacity to make it effective. But in the immediate future, that solution remains unlikely, and to make it a condition of lawful decision now only evades addressing the policies that the notion of popular sovereignty encapsulates. The given of contemporary international decision making is the absence of such institutions and the need to focus on regulating unilateral decision making. Because rights without remedies are not rights at all, prohibiting the unilateral vindication of clear violations of rights when multilateral possibilities do not obtain is virtually to terminate those rights.

It is no longer politically feasible or morally acceptable to suspend the operation of human rights norms until every constitutive problem is solved. In the interim, new criteria for unilateral human rights actions must be established. In addition, more refined techniques for their legal appraisal and more effective means for their condemnation when such actions are themselves unlawful must be developed. One contribution of our profession

\footnotetext{
${ }^{31}$ See, t.g., Reisman \& Silk, supra note 12, at 466-79 (discussion of factual situation in Afghanistan leading to "invitation" of Soviet armed forces by Afghan "government").
} 
should be to develop methods for assessing popular will and making judgments about divergences.

The violation of sovereignty has heretofore largely been treated with passive strategies: absorbing those who have been obliged to flee their own countries. With the increasing refinement of transportation, domestic human rights pathologies now generate larger and larger numbers of refugees. But the welfare democracies of the world, which are the preferred refuge of those fleeing human rights violations in their own countries, have begun to reach the limits of their absorptive capacities. The passive strategy of dealing with violations of sovereignty will no longer work. An active strategy that addresses the pathology itself is required, both pragmatically and by the very conception of modern sovereignty.

VI.

Because human rights considerations introduce so many more variables into the determination of lawfulness, an even heavier burden of deliberation devolves upon international lawyers in assessing the lawfulness of actions. Matters become more complex and uncertain than they were in an international legal system that was composed of a few binary rules applied to a checkerboard of monarchical states and, most particularly, that lacked an international code of human rights. One can no longer simply condemn externally motivated actions aimed at removing an unpopular government and permitting the consultation or implementation of the popular will as per $s e$ violations of sovereignty without inquiring whether and under what conditions that will was being suppressed, and how the external action will affect the expression and implementation of popular sovereignty. The identification of what is clearly "externally motivated action" is itself an increasingly difficult task.

No one is entitled to complain that things are getting too complicated. If complexity of decision is the price for increased human dignity on the planet, it is worth it. Those who yearn for "the good old days" and continue to trumpet terms like "sovereignty" without relating them to the human rights conditions within the states under discussion do more than commit an anachronism. They undermine human rights.

W. Michael REISMAN 